\title{
A DNA Controlled-Release Coating for Gene Transfer: Transfection in Skeletal and Cardiac Muscle
}

\author{
Vinod Labhasetwar, ${ }^{\dagger}$ Jeffrey Bonadio, ${ }^{\ddagger}$ Steven Goldstein, ${ }^{\ddagger}$ Wellam Chen,$\S$ and Robert J. Levy ${ }^{\star} \S$
}

Contribution from Department of Pharmaceutical Sciences, University of Nebraska Medical Center, Omaha, Nebraska 68198, University of Michigan, Ann Arbor, Michigan 48109, and Children's Hospital of Philadelphia, Abramson Pediatric Research Center, Room 1170B, 34th Street and Civic Center Boulevard, Philadelphia, Pennsylvania 19104-4318.

Received March 13, 1998. Accepted for publication April 28, 1998.

\begin{abstract}
In this paper we report a novel technique of DNA-polymer coating for gene transfer. A proprietary DNA polymer solution was used for thin-layer coating on a chromic gut suture as a model study. The coated sutures were characterized for physical properties such as coating thickness, mass of the DNA deposited on the suture, surface characteristics as determined by scanning electron microscopy, and in vitro DNA release characteristics under simulated physiologic conditions. The in vivo gene transfection using DNA-coated sutures was demonstrated in rat skeletal muscle and in canine atrial myocardium. A heat-stable human placental alkaline phosphatase (AP) plasmid was used as a marker gene. Incisions of 1 to $1.5 \mathrm{~cm}$ were made in the rat skeletal muscles or the canine atrial myocardium. The sites were closed with either the DNA-coated sutures or control sutures. Two weeks after the surgery, the tissue samples adjacent to the suture lines were retrieved and analyzed for AP activity. The DNA-coated sutures demonstrated a sustained release of the DNA under in vitro conditions, with an $\sim 84 \%$ cumulative DNA release occurring in 26 days. An agarose gel electrophoresis of the DNA samples released from the suture demonstrated two bands, with the lower band corresponding to the input DNA (supercoiled). It seems that there was a partial transformation of the DNA from a supercoiled to an open circular form due to the polymer coating. The tissue sites, which received the DNA-coated sutures, demonstrated a significantly higher AP activity compared with the tissue sites that received control sutures. In the rat studies, the mean AP activity (square root of $\mathrm{cpm} /$ $\mu \mathrm{g}$ protein) was $43.6 \pm 3.3$ vs $20.6 \pm 2.1(p=0.001)$ at the control sites. Similarly, in the canine studies, the AP activity was $73.6 \pm 7.4$ Vs $21.6 \pm 1.4(p=0.0009)$ at the control sites. Thus, our studies demonstrated a successful gene transfer using our DNA-polymer coating technique. This technique could be useful for coating sutures used in vascular and general surgery, and also for coating medical devices, such as stents, catheters, or orthopedic devices, to achieve a site-specific gene delivery.
\end{abstract}

\section{Introduction}

The concerns associated with viral vectors for gene delivery, ${ }^{1-3}$ such as immunogenicity with the adenoviral vectors or the risk of mutation with the retroviral vectors, have led to a renewed interest in investigating nonviral methods of gene delivery. ${ }^{4-9}$ A variety of nonviral methods of gene delivery including liposomes, ${ }^{10,11}$ cationic lipidDNA complexes, ${ }^{12,13}$ and cationic polymer-DNA condensates ${ }^{14-16}$ are under investigation. However, the important limiting factor with the nonviral methods of gene delivery is their comparative inefficiency to facilitate cellular uptake of DNA and gene expression. ${ }^{17,18}$

* Corresponding author. Phone: 215-590-6119. Fax: 215-5905454. E-mail: LEVY@EMAIL.CHOP.EDU.
Sustained-release drug delivery systems are currently being investigated for DNA. These formulations include microspheres, nanospheres, and polymer matrixes. The DNA is either entrapped or dispersed into the polymer matrix or adsorbed onto the surface. Biodegradable (polyesters, polyanhydrides) and nonbiodegradable polymers (ethylene vinyl acetate copolymers), either synthetic or natural (collagen, gelatin), have been investigated for formulating sustained-release delivery systems. ${ }^{19}$ These systems have demonstrated their efficacy for the sustained delivery of proteins and peptides, which are comparatively unstable in biological systems and require multiple dosing to maintain a prolonged therapeutic effect. ${ }^{20-22}$

Sustained-release DNA delivery systems, in addition to providing a controlled release of DNA, could also protect the entrapped DNA from degradation due to nucleases. Prolonged availability of the DNA released slowly from the sustained-release DNA delivery system at the site of an implant could increase the efficiency of cellular DNA uptake. This prolonged availability could also lead to a prolong duration of gene expression. In this paper, we have described a novel DNA-polymer coating method for the sustained delivery of DNA. A heat-stable human placental alkaline phosphatase (AP) plasmid was used as a marker gene. The goals of the studies were (1) to formulate a sustained-release DNA coating; (2) to characterize the DNA coating, study in vitro release characteristics of the DNA, and characterize the DNA released from the coating; and (3) to demonstrate in vivo gene expression in animal model studies.

\section{Materials and Methods}

Materials-A proprietary biodegradable DNA-polymer coating preparation was obtained from Matrigen, Inc. (Ann Arbor, MI). Trizama- $\mathrm{HCl}$ (Tris(hydroxymethyl)aminomethane) and ethylenediaminetetraacetic acid (EDTA) sodium salt were obtained from Sigma Chemicals (St. Louis, MO). The following assay kits were purchased: Alkaline Phosphatase Enzyme Kit (Phospho-Light) from Tropiz, Inc. (Bedford, MA) and BCA Protein Assay Kit from Pierce (Rockford, IL). Potassium phosphate, urea, and potassium chloride were obtained from Mallinckrodt Specialty Chemical Company (Paris, KY). All organic solvents and reagents were either of HPLC grade or American Chemical Society analytical grade reagents.

Plasmid DNA Sustained-Release Preparation-The plasmid pcDNA3 (Invitrogen, Carlsbad, CA), containing a human placental alkaline phosphatase gene under the control of human cytomegalovirus (CMV) promoter, was propagated in Eschericia coli and was isolated using a Qiagen UItrapure column (Qiagen, Inc., Chatswirth, CA). The structure and purity of the plasmid preparation was assessed by agarose gel $(0.8 \%)$ electrophoresis in the presence of ethidium bromide to detect DNA bands. The concentration of DNA in the plasmid preparation was determined by ultraviolet (UV) spectrophotometric absorption at 260/280 nm wavelengths. The plasmid DNA was incorporated into the Matri-
(C) 1998, American Chemical Society and American Pharmaceutical Association
Journal of Pharmaceutical Sciences / 1347 Vol. 87, No. 11, November 1998 
gen coating system and applied to a 3-0 Chromic gut suture (Ethicon, Inc. Somerville, NJ ).

DNA-Polymer Coating-Two proprietary formulations of coating, varying in DNA dose, were investigated. The high-dose formulation contained $3.0 \mathrm{mg}$ of DNA and the other formulation contained $1.0 \mathrm{mg}$ of DNA per 70-cm length of suture. A multilayer solventcasting procedure was used for the DNA-polymer coating. The coating was dried in air first for $3-4 \mathrm{~h}$ and then under desiccation for $48 \mathrm{~h}$.

Characterization of DNA Suture-The DNA-coated sutures were characterized for the mass weight increase, for surface characteristics by scanning electron microscopy, and for in vitro release of the DNA under physiologic conditions.

Scanning Electron Microscopy-A piece of coated and uncoated suture was sputtered with carbon and was observed under a scanning electron microscope (Amray, Model 1810, Bedford, MA) at 150X magnification.

In Vitro Release of DNA-A DNA-coated suture (total length = $70 \mathrm{~cm}$ ) was cut into pieces $\sim 7 \mathrm{~cm}$ in length. The pieces were incubated with a Tris-EDTA buffer $(\mathrm{pH} \mathrm{7.3,50} \mathrm{mM,} 5 \mathrm{~mL})$ at 37 ${ }^{\circ} \mathrm{C}$ on a rotary shaker at $110 \mathrm{rpm}$. The buffer was replaced at regular intervals of time. The experiment was performed in triplicate. The samples were assayed for the DNA concentration by high-pressure liquid chromatography (HPLC) as described next. The samples were also analyzed by agarose gel electrophoresis $(0.8 \%$ agarose, $100 \mathrm{~V}, 40 \mathrm{~min})$ to test the integrity of the released DNA.

HPLC Analysis of DNA-The HPLC system (Waters Company Milford, MA) consisted of two 501 pumps, an automated gradient controller, a 712 WISP autosampler, a 481 Lambda-Max UV detector, and a 756 Data module. A Nucleogen DEAE 4000-7 (Alltech, San J ose, CA) column was used for the DNA separations using a mobile phase consisting of $5 \mathrm{M}$ urea and $0.2 \mathrm{M}$ potassium phosphate adjusted to $\mathrm{pH}$ 6.5. The gradient was created with potassium chloride $(0.2-1.5 \mathrm{M})$. $^{23}$ The flow rate was set at $2 \mathrm{~mL} /$ min, and separations were monitored at $260 \mathrm{~nm}$. A 100- $\mu \mathrm{L}$ sample was injected for the purpose of DNA quantitation. Standard curves of the input DNA were created for quantitation.

In Vivo Gene Expression-Rat Skeletal Muscle Wound Closure-Six-week-old Sprague-Dawley rats (Charles River Laboratories, Burlington, MA) were used for this study. Animals were anesthetized with an intramuscular injection $(0.001 \mathrm{~mL} / \mathrm{kg}$ ) of a combination $(4: 3 \mathrm{v} / \mathrm{v})$ of ketamine $(100 \mathrm{mg} / \mathrm{mL})$ and xyalazine (20 $\mathrm{mg} / \mathrm{mL}$ ). Under sterile conditions, the skin in the area of the hindlimb was opened and 1-cm incisions were made with a scalpel in the femoral extensor musculature. The wounds were closed with either control or DNA-coated sutures (low-dose DNA suture, $260 \mu \mathrm{g}$ of DNA per site). Two weeks after the surgery, the tissue from the incision sites adjacent to the suture lines were retrieved and stored frozen $\left(-70^{\circ} \mathrm{C}\right)$ until taken for the determination of the AP activity.

Canine Atrial Myocardium Wound Closure-This experiment was performed with a male mongrel dog weighing $30 \mathrm{~kg}$. The animal was anesthetized with an injection of sodium pentobarbital (35 mg/kg), and anesthesia was maintained with halothane. Under sterile conditions, the chest was opened and the heart was exposed. A total of four incisions, each $\sim 1.5 \mathrm{~cm}$, were made in the right atrium of the heart. The wounds at two of the sites were closed with the DNA-coated sutures (high-dose DNA suture, 780 $\mu \mathrm{g}$ per site) and at the other two sites with control sutures. The DNA sites were $\sim 8-10 \mathrm{~cm}$ away from the control sites. After 2 weeks, the animal was euthanized with an overdose of pentobarbital, and the tissue samples from the atrium adjacent to the suture linings were retrieved for analysis of AP activity.

Assay for Alkaline Phosphatase (AP) Activity-The frozen samples were thawed, homogenized in TMNC buffer [ $50 \mathrm{mM}$ Tris $\mathrm{pH} 7.4,5 \mathrm{mM} \mathrm{MgCl} 2,100 \mathrm{mM} \mathrm{NaCl}$, and 4\% CHAPS (3-[(3cholamidopropyl)-dimethylammonium]-1-propene sulfonate; $1 \mathrm{~g}$ tissue/2.5 mL buffer] and centrifuged at $4000 \times \mathrm{g}$ for $15 \mathrm{~min}$. The supernatants were heated at $65{ }^{\circ} \mathrm{C}$ for $30 \mathrm{~min}$ to inactivate the intrinsic cellular AP. A $20-\mu \mathrm{L}$ aliquot of the supernatant was mixed with a $100 \mu \mathrm{L}$ of the assay solution and incubated at room temperature for $5 \mathrm{~min}$. The substrate $(100 \mu \mathrm{L})$ was added to the aforementioned mixture and again incubated at room temperature for $20 \mathrm{~min}$. The light output (cpm) was measured with a liquid scintillation counter (Beckman LS-100, Fullerton, CA) on the ${ }^{3} \mathrm{H}$ channel with the coincidence circuit on. The assay results were normalized to the tissue protein concentration as determined by

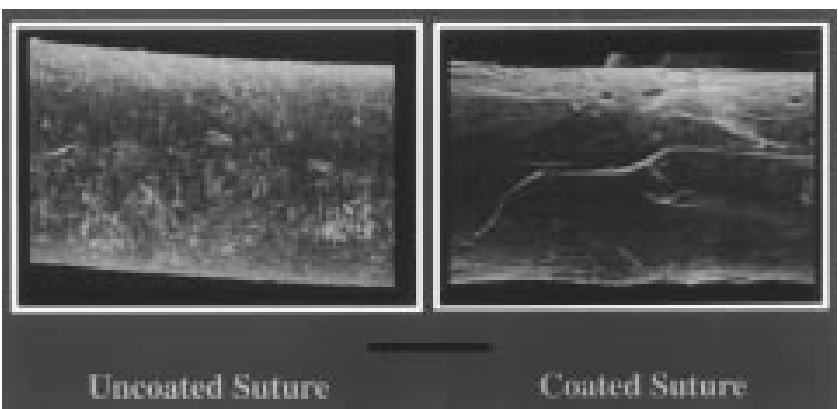

Figure 1-Scanning electron micrograph of an uncoated and the DNA-polymercoated suture. The bar represents $280 \mu \mathrm{m}$.

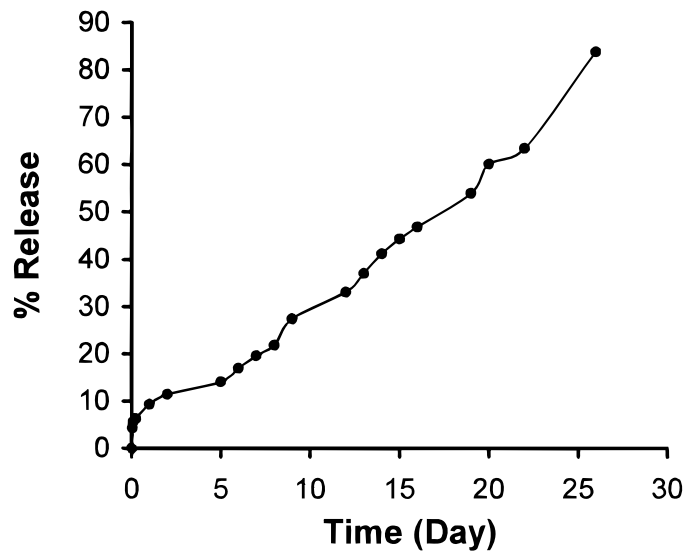

Figure 2-In vitro release of DNA from the DNA-coated suture under simulated physiologic conditions.

the standard bicinchoninic acid (BCA) protein assay using bovine serum albumin as a standard. The results were calculated as a square root of the activity (cpm) per amount $(\mu \mathrm{g})$ of protein.

Statistical Analysis-Values were expressed as mean \pm standard error of mean (SEM). Comparisons were made using a paired t-test as appropriate. A probability value (p) of $<0.05$ was considered significant.

\section{Results}

The overall results demonstrated a successful DNApolymer coating methodology, sustained DNA release characteristics, and in vivo gene expression in model studies.

Characterization of DNA Coated Suture-The coating resulted in a total deposition of $35 \pm 2.5(n=6) \mathrm{mg}$ of DNA polymer-coating preparation. Based on the amount of DNA load in the coating formulation, the DNA coated per entire suture length $(70 \mathrm{~cm})$ was $777.2 \pm 0.05 \mu \mathrm{g}$. The coating also resulted in a $30-\mu \mathrm{m}$ increase in the suture thickness. The scanning electron micrograph demonstrates a uniform coating of the DNA-containing polymer (F igure $1)$, which is distinctly different from the surface of the uncoated suture. The coating seems to have no effect on the physical properties of the suture that would affect its ability to function as a wound closure.

The in vitro release studies demonstrated sustained DNA release characteristics with a 9.3\% cumulative release occurring during the first $24 \mathrm{~h}$ as a burst phase, followed by a gradual elution with $84 \%$ cumulative release occurring in 26 days (Figure 2). The coating was found to detach from the suture after $\sim 3$ weeks of the in vitro release study. Thus, the DNA release from the coating seems to be due to degradation of the polymer matrix. The DNA samples released from the sutures demonstrated two bands of an almost equal intensity on the agarose gel electrophoresis, with a lower band corresponding to the original DNA 
a b c d e f

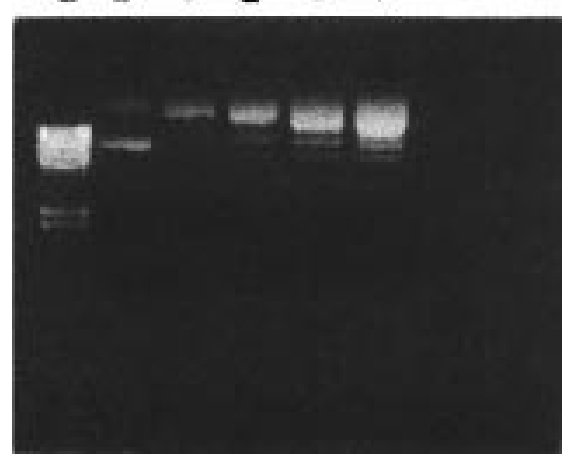

Figure 3-Results of agarose gel electrophoresis of the DNA samples released under in vitro conditions from the DNA-coated suture. (a) DNA ladder (75 base pairs to 23 Kilobase pairs; (b) input plasmid DNA, human placental alkaline phosphatase, (c) 5-day controlled-release sample (2 $\mu \mathrm{L})$; (d) 5-day controlled-release sample (5 $\mu \mathrm{L})$; (e) 8-day controlled-release sample $(4 \mu \mathrm{L})$; (f) 8-day controlled-release sample $(10 \mu \mathrm{L})$.

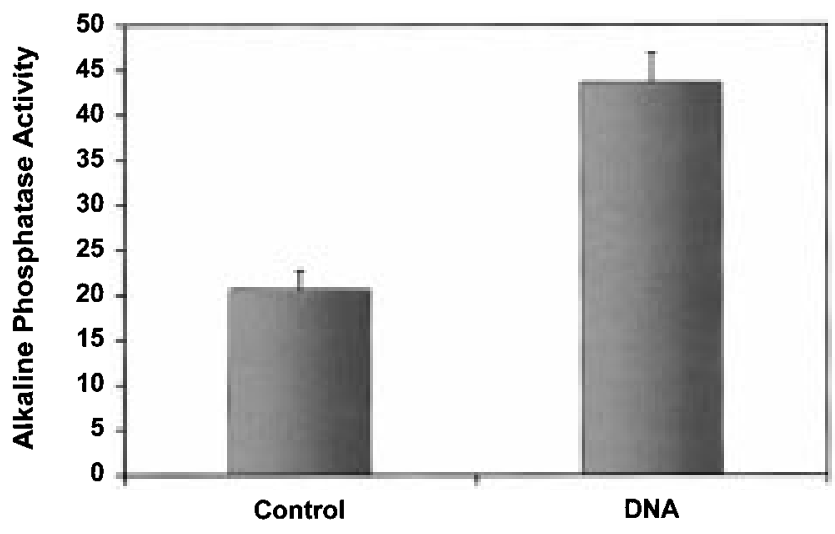

Type of Suture

Figure 4-Alkaline phosphatase activity in rat skeletal muscles at DNA-coated suture sites $(n=14)$ and control sites $(n=5)$. The AP activity is represented as a square root of the activity $(\mathrm{cpm})$ normalized activity to amount $(\mu \mathrm{g})$ of protein. Data as mean \pm sem.

(supercoiled) (Figure 3). These data indicate that there was a partial transformation of DNA from a supercoiled to an open circular form. A similar transformation of the DNA was observed in studies by J ong et al. ${ }^{24}$ when the DNA was dispersed in the EVAc matrixes. As the solvent from the DNA polymer coating solution evaporates, the DNA is compressed in the polymer matrix. The physical forces encountered during such entrapment could be responsible for a transformation of DNA. ${ }^{25}$

In Vivo Gene Expression-Each incision site received $1 / 3$ of the suture length $(\sim 23 \mathrm{~cm})$, which represents a total DNA dose of $260 \mu \mathrm{g}$ per site (or $7.6 \mu \mathrm{g} /$ day) in rat studies and $780 \mu \mathrm{g}$ per site (or $22.8 \mu \mathrm{g} /$ day) in dog studies. The estimated dose was calculated from the DNA load in the suture coatings and the in vitro DNA release characteristics. There was no apparent inflammatory or untoward tissue reactions at the incision site, indicating that the coated sutures were well tolerated.

The tissue retrieved from the DNA suture site had significantly higher AP activity compared with AP activity in the tissue retrieved from the control suture sites. The mean AP activity in the rat studies was $43.6 \pm 3.3$ in the DNA delivery sites vs $20.6 \pm 2.1(p=0.001)$ at the control sites (Figure 4). Similarly, in the canine studies, the mean AP activity was $73.6 \pm 7.4$ in the DNA controlled-release sites vs $21.6 \pm 1.4(p=0.0009)$ at the control sites. The AP activity was represented as a square root of the activity in cpm normalized to protein content $(\mu \mathrm{g})$. The AP activity in canine tissue samples was comparatively higher than that in the rat tissues. This difference could reflect a dose effect, because the sutures used in the dog studies had three-fold higher DNA loading than the sutures used in the rat studies.

\section{Discussion}

Our study demonstrated a novel DNA coating technique for sustained DNA delivery. Successful in vivo gene expression was demonstrated in rat skeletal muscles and in canine myocardium. Sustained DNA delivery systems offer many advantages over plasmid DNA solution administration in which the injected DNA could be rapidly washed out from the site of administration or it could undergo rapid degradation by nudeases. It is also known that the injected DNA (e.g., intramuscular or subcutaneous injections) drains rapidly into the lymphatics in certain tissue, ${ }^{26,27}$ which could also significantly limit the availability of DNA. Sustained-release systems could prolong the availability of the DNA, which could also lead to a sustained duration of gene expression.

Other investigators have also demonstrated gene expression using sustained-release DNA delivery systems. Fang et al. ${ }^{28}$ demonstrated gene expression in a rat bone fracture model, which was packed with collagen sponge soaked in a DNA solution for several hours before implantation. Their studies demonstrated induction of new bone formation with therapeutic genes (PTH-34 and BMP-4). Collagen is probably serving a twofold function in this experiment: as a scaffold for the migrating cells and sustained delivery of DNA. In another study, gene expression was demonstrated on the serosal side of the intestine in rats that received oral administration of polyanhydride microspheres containing a marker DNA ( $\beta$-galactosi dase). ${ }^{29}$ The bioadhesive characteristics of the polyanhydride microspheres provided sustained release of DNA at localized sites in the intestine. We have also demonstrated gene expression in the rabbit iliac arterial wall following a local infusion of PLGA nanospheres containing AP plasmid DNA. ${ }^{30}$

Our coating technique could be useful for medical devices such as stents, catheters, or orthopedic devices, to deliver therapeutic genes locally at the site of implant. Stents coated with a therapeutic gene could be useful for preventing restenosis. Myocardial gene expression has many therapeutic applications, such as inducing angiogenesis in the damaged myocardium, or expression of a gene that could modulate pathways of electrical conductance to control cardiac arrhythmias. ${ }^{39-44}$ In addition, coated sutures with an appropriate therapeutic gene (TGF - $\beta$ ) could be used to enhance the wound healing process. ${ }^{45}$ Coating of scaffolds with genes in tissue engineering is yet another application of our coating technique. ${ }^{46}$

\section{Conclusions}

Our studies have demonstrated a novel method of DNA coating for the sustained release of plasmid DNA. Our rat and canine studies demonstrated in vivo reporter gene expression using DNA-coated sutures. We conclude this DNA delivery system offers the capability of incorporating sustained-release DNA into virtually any implantable or interventional device. Thus, surgical and invasive procedures, as well as wound dressings, could be enhanced through the coincorporation of the DNA delivery system described in these studies. Therapeutic DNA administration could therefore be broadly used in a site-specific manner with this technique. 


\section{References and Notes}

1. Crystal, R. G. Transfer of Genes to Humans: Early Lessons and Obstacles to Success. Science 1995, 270, 404-410.

2. Marshall, E. Gene Therapy's Growing Pains. Science 1995, 269, 1050, 1052-1055.

3. Stewart, F. M. Getting Human Gene Therapy to Work. J . Cell Biochem. 1995, 58, 416-423.

4. Felgner, P. L. Nonviral Strategies for Gene Therapy. Sci. Am. 1997, 276, 102-106

5. Ledley, F. D. Pharmaceutical Approach to Somatic Gene Therapy. Pharm. Res. 1996, 13, 1595-1614.

6. Mahato, R. I.: Takakura, Y.: Hashida, M. Nonviral Vectors for In Vivo Gene Delivery: Physicochemical and Pharmacokinetic Considerations. Crit. Rev. Ther. Drug Carrier Syst. 1997, 14, 133-172.

7. Mumper, R. J .; Duguid, J. G.; Anwer, K.; Barron, M. K.; Nitta, H.; Rolland, A. P. Polyvinyl Derivatives as Novel Interactive Polymers for Controlled Gene Delivery to Muscle. Pharm. Res. 1996, 13, 701-709.

8. Schofield, J. P.; Caskey, C. T. Nonviral Approaches to Gene Therapy. Br. Med. Bull. 1995, 51, 56-71.

9. Crystal, R. G. The Gene as the Drug. Nat. Med. 1995, 1, 1517.

10. Hsiao, M.; Tse, V.; Carmel, J .; Tsai, Y.; Felgner, P. L.; Haas, M.; Silverberg, G. D. Intracavitary Liposome-mediated p53 Gene Transfer into Glioblastoma with Endogenous Wild-type p53 In Vivo Results in Tumor Suppression and Long-term Survival. Biochem. Biophys. Res. Commun. 1997, 233, 359364.

11. Huang, L.; Li, S. Liposomal Gene Delivery: A Complex Package [news]. Nat. Biotechnol. 1997, 15, 620-621.

12. Bebok, Z.; Abai, A. M.; Dong, J. Y.; King, S. A.; Kirk, K. L.; Berta, G.; Hughes, B. W.; Kraft, A. S.; Burgess, S. W.; Shaw, W.; Felgner, P. L.; Sorscher, E. J. Efficiency of Plasmid Delivery and Expression After Lipid-mediated Gene Transfer to Human Cells In Vitro. J . Pharmacol. Exp. Ther. 1996, 279, $1462-1469$.

13. Gorman, C. M.; Aikawa, M.; Fox, B.; Fox, E.; Lapuz, C. Michaud, B.; Nguyen, H.; Roche, E.; Sawa, T.; Wiener Kronish, J. P. Efficient In Vivo Delivery of DNA to Pulmonary Cells Using the Novel Lipid EDMPC. GeneTher. 1997 4, 983-992.

14. Astafieva, I.; Maksimova, I.; Lukanidin, E.; Alakhov, V.; Kabanov, A. Enhancement of the Polycation-mediated DNA Uptake and Cell Transfection with Pluronic P85 Block Copolymer. FEBS Lett. 1996, 389, 278-280.

15. Boletta, A.; Benigni, A.; Lutz, J .; Remuzzi, G.; Soria, M. R.; Monaco, L. Nonviral Gene Delivery to the Rat Kidney with Polyethylenimine. Hum. Gene Ther. 1997, 8, 1243-1251.

16. Gottschalk, S.; Sparrow, J . T.; Hauer, J .; Mims, M. P.; Leland, F. E.; Woo, S. L.; Smith, L. C. A Novel DNA-peptide Complex for Efficient Gene Transfer and Expression in Mammalian Cells. Gene Ther. 1996, 3, 48-57.

17. Thierry, A. R.; Rabinovich, P.; Peng, B.; Mahan, L. C.; Bryant . L.; Gallo, R. C. Characterization of Liposome-mediated Gene Delivery: Expression, Stability and Pharmacokinetics of Plasmid DNA. Gene Ther. 1997, 4, 226-237.

18. Wu, G. Y.; Wu, C. H. Delivery Systems for Gene Therapy. Biotherapy 1991, 3, 87-95.

19. Labhasetwar, V.; Levy, R. J . Polymer Systems for Cardiovascular Drug Delivery. Polym. News 1992, 17, 336-342.

20. Langer, R. Controlled Release of a Therapeutic Protein. Nat Med. 1996, 2, 742-743.

21. Edwards, D. A.; Hanes, J .; Caponetti, G.; Hrkach, J .; Ben J ebria, A.; Eskew, M. L.; Mintzes, J .; Deaver, D.; Lotan, N.; Langer, R. Large Porous Particles for Pulmonary Drug Delivery. Science 1997, 276, 1868-1871.

22. J ohnson, O. L.; J aworowicz, W.; Cleland, J . L.; Bailey, L.; Charnis, M.; Duenas, E.; Wu, C.; Shepard, D.; Magil, S.; Last, T.; J ones, A. J .; Putney, S. D. The Stabilization and Encapsulation of Human Growth Hormone into Biodegradable Microspheres. Pharm. Res. 1997, 14, 730-735.

23. Horn, N. A.; Meek, J. A.; Budahazi, G.; Marquet, M. Cancer Gene Therapy Using Plasmid DNA: Purification of DNA for Human Clinical Trials. Hum. GeneTher. 1995, 6, 565-573.

24. J ong, Y. S.; J acob, J . S.; Yip, K.-P.; Gardner, G.; Seitelman E.; Whitney, M.; Montgomery, S.; Mathiowitz, E. Controlled Release of Plasmid DNA. J . Controlled Release 1997, 47, 123-134.

25. Wasan, E. K.; Reimer, D. L.; Bally, M. B. Plasmid DNA is Protected Against Ultrasonic Cavitation-induced Damage
When Complexed to Cationic Liposomes. J. Pharm. Sci. 1996, 85, 427-433.

26. Choate, K. A.; Khavari, P. A. Direct Cutaneous Gene Delivery in a Human Genetic Śkin Disease. Hum. Gene Ther. 1997, 8, 1659-1665.

27. Levy, M. Y.: Barron, L. G.; Meyer, K. B.: Szoka, F. C., J r. Characterization of Plasmid DNA Transfer into Mouse Skeletal Muscle: Evaluation of Uptake Mechanism, Expression and Secretion of Gene Products into Blood. Gene Ther. 1996, 3, 201-211.

28. Fang, J .; Zhu, Y. Y.; Smiley, E.; Bonadio, J .; Rouleau, J . P.; Goldstein, S. A.; McCauley, L. K.; Davidson, B. L.; Roessler, B. J . Stimulation of New Bone Formation by Direct Transfer of Osteogenic Plasmid Genes. Proc. Natl. Acad. Sci. U.S.A. 1996, 93, 5753-5758.

29. Mathiowitz, E.; J acob, J . S.; J ong, Y. S.; Carino, G. P. Chickering, D. E.; Chaturvedi, P.; Santos, C. A.; Vijayaraghavan, K.; Montgomery, S.; Bassett, M.; Morrell, C. Biologically Erodable Microspheres as Potential Oral Drug Delivery Systems. Nature 1997, 386, 410-414.

30. Labhasetwar, V.; Chen, B.; Muller, D. W. M.; Bonadio, J .; Ciftci, K.; March, K.; Levy, R. J . Gene-based Therapies for Restenosis. Adv. Drug Del. Rev. 1997, 24, 109-120.

31. Schmidt Wolf, G. D.; Schmidt Wolf, I. G. Cancer and Gene Therapy. Ann. Hematol. 1996, 73, 207-218.

32. Mulligan, R. C. The Basic Science of Gene Therapy. Science 1993, 260, 926-932.

33. Meyers, A. S. GeneTherapy and Genetic Diseases: Revisiting the Promise. Hum. GeneTher. 1994, 5, 1201-1202.

34. Taneja, S. S.; Pang, S.; Cohan, P.; Belldegrun, A. Gene Therapy: Principles and Potential. Cancer Surv. 1995, 23 247-266.

35. Werner, R. G. Gene Technology: Chances for Diagnosis and Therapy. Methods Find. Exp. Clin. Pharmacol. 1994, 16, 525-537.

36. Dickler, H. B.; Collier, E. Gene Therapy in the Treatment of Disease. J. Allergy Clin. Immunol. 1994, 94, 942-951.

37. Bout, A. Prospects for Human Gene Therapy. Eur. J . Drug Metab. Pharmacokinet. 1996, 21, 175-179.

38. Afione, S. A.; Conrad, C. K.; Flotte, T. R. Gene Therapy Vectors as Drug Delivery Systems. Clin. Pharmacokinet. 1995, 28, 181-189.

39. Coffin, R. S.; Howard, M. K.; Cumming, D. V.; Dollery, C. M.; McE wan, J .; Yellon, D. M.; Marber, M. S.; MacLean, A. R.; Brown, S. M.; Latchman, D. S. Gene Delivery to the Heart: In Vivo and to Cardiac Myocytes and Vascular Smooth Muscle Cells In Vitro Using Herpes Virus Vectors. Gene Ther. 1996, 3, 560-566.

40. Gal, D.; Weir, L.; Leclerc, G.; Pickering, J. G.; Hogan, J .; Isner, J. M. Direct Myocardial Transfection in Two Animal Models. Evaluation of Parameters Affecting Gene Expression and Percutaneous Gene Gelivery. Lab. I nvest. 1993, 68, 1825.

41. Malosky, S.; Kolansky, D. M. Gene Therapy for Ischemic Heart Disease. Curr. Opin. Cardiol. 1996, 11, 361-368.

42. Yla Herttuala, S. Gene Therapy for Cardiovascular Diseases. Ann. Med. 1996, 28, 89-93.

43. von Harsdorf, R.; Schott, R. J .; Shen, Y. T.; Vatner, S. F.; Mahdavi, V.; Nadal Ginard, B.' Gene Injection into Canine Myocardium as a Useful Model for Studying Gene Expression in the Heart of Large Mammals. Circ. Res. 1993, 72, 688695

44. Nabel, E. G. Gene therapy for Cardiovascular Disease. Circulation 1995, 91, 541-548.

45. Gerich, T. G.; Kang, R.; Fu, F. H.; Robbins, P. D.; Evans, C. $\mathrm{H}$. Gene Transfer to the Rabbit Patellar Tendon: Potential for Genetic Enhancement of Tendon and Ligament Healing. Gene Ther. 1996, 3, 1089-1093.

46. Langer, R. Tissue Engineering: A New Field and Its Challenges. Pharm. Res. 1997, 14, 840-841.

\section{Acknowledgments}

This work was supported by funding from Matrigen, Inc., Ann Arbor, MI. Dr. Levy's efforts were partially supported by an Endowed Chair at the Children's Hospital of Philadelphia. It is also disclosed that some of the authors (VL, J B, SG, RJ L) may potentially benefit from the results.

J S980077+ 